\title{
Are recommended doses of efavirenz optimal in young children?
} (ANRS I 2 I 03)

\author{
Déborah Hirt*1,2, Saïk Urien², Mathieu Olivier"4, Hélène Peyrière4, \\ Boubacar Nacro ${ }^{5}$, Serge Diagbouga ${ }^{6}$, Emmanuelle Zouré $e^{5}$, François Rouet ${ }^{6}$, \\ Hervé Hien ${ }^{6}$, Philippe Msellati ${ }^{7}$, Philippe Van de Perre ${ }^{8,9}$ and Jean- \\ Marc Tréluyer ${ }^{3,1}$
}

Address: ${ }^{1}$ Université paris-descartes, Paris, France, ${ }^{2}$ Hôpital Tarnier, Paris, France, ${ }^{3}$ Hôpital Cochin-Saint Vincent de Paul, Paris, France, ${ }^{4}$ Hôpital Lapeyronie, Montpellier, France, ${ }^{5} \mathrm{CHU}$ Sourô Sanou, Bobo Dioulasso, Burkina Faso, ${ }^{6}$ Centre Muraz, Bobo Dioulasso, Burkina Faso, ${ }^{7}$ Université Paul Cézanne, Aix en Provence, France, ${ }^{8}$ Hôpital Arnaud de Villeneuve, Montpellier, France and ${ }^{9}$ Université Montpellier 1, Montpellier, France

* Corresponding author

from Fifth Dominique Dormont International Conference. Mother-to-child transmitted viral diseases: from transmission to children care Paris, France. 26-28 March 2009

Published: 22 July 2009

Retrovirology 2009, 6(Suppl I):PI9 doi:10.1 186/1742-4690-6-SI-PI9

This abstract is available from: http://www.retrovirology.com/content/6/SI/PI9

(C) 2009 Hirt et al; licensee BioMed Central Ltd.

\section{Background}

Pediatric studies suggested that the actual recommended efavirenz dosage produced insufficient plasma concentrations in children. In the context of a phase II trial on oncea-day pediatric HAART, the aims of this study were to describe efavirenz concentration-time courses in treatment naïve children, to study the effect of age and bodyweight on efavirenz pharmacokinetics and to test relationships between doses, plasma concentrations and efficacy.

\section{Methods}

Efavirenz concentrations were measured in 48 children after 2 weeks of didanosine - lamivudine - efavirenz treatment, and samples were available in $9 / 48$ children between month 2 and 5 of treatment. A total of 200 efavirenz plasma concentrations were collected and a population pharmacokinetic model was developed with NONMEM. The influence of individual characteristics was tested using a likelihood ratio test. Estimated minimal $\left(\mathrm{C}_{\min }\right)$, maximal $\left(\mathrm{C}_{\max }\right)$ concentrations, area under the curve (AUC) were correlated to the decrease in HIV-1 RNA levels after 3 months of treatment. The threshold $\mathrm{C}_{\min }$ (and AUC) improving efficacy was determined. The target minimal concentration of $4 \mathrm{mg} / \mathrm{L}$ was considered for tox- icity. An optimized dosing schedule was simulated in order that the higher percentage of children is in the effective and not toxic concentrations interval.

\section{Results}

Efavirenz pharmacokinetics was best described by a onecompartment model with first order absorption and elimination. Mean efavirenz apparent elimination clearance and volume of distribution were respectively $0.211 \mathrm{~L} / \mathrm{h} / \mathrm{kg}$ and $4.48 \mathrm{~L} / \mathrm{kg}$. The elimination clearance significantly decreased with age. With the recommended doses given to 46 out of the 48 children, $19 \%$ had a minimal concentration below $1 \mathrm{mg} / \mathrm{L}$; they were $44 \%$ under this limit in the less than $15 \mathrm{~kg}$ children. A significant higher percentage of children with $\mathrm{C}_{\min }>1.1 \mathrm{mg} / \mathrm{L}$ (or AUC $>51 \mathrm{mg} / \mathrm{L} . \mathrm{h}$ ) had a viral load decrease greater than $2 \log _{10}$ copies/mL after 3 months of treatment, compared to children below these values.

\section{Conclusion}

To optimize the percentage of children with a $\mathrm{C}_{\text {min }}$ between 1.1 and $4 \mathrm{mg} / \mathrm{L}$, children should receive the following once daily efavirenz dose: $25 \mathrm{mg} / \mathrm{kg}$ from 2 to 6 years, $15 \mathrm{mg} / \mathrm{kg}$ from 6 to 10 years and $10 \mathrm{mg} / \mathrm{kg}$ from 10 
to 15 years. These assumptions should be prospectively confirmed.

Publish with Bio Med Central and every scientist can read your work free of charge

"BioMed Central will be the most significant development for disseminating the results of biomedical research in our lifetime. " Sir Paul Nurse, Cancer Research UK

Your research papers will be:

- available free of charge to the entire biomedical community

- peer reviewed and published immediately upon acceptance

- cited in PubMed and archived on PubMed Central

- yours - you keep the copyright 